(1)

\title{
Effect of adhesive type and composite viscosity on the dentin bond strength
}

\section{Graziela Ribeiro Batista, Daphne Câmara Barcellos \& Carlos Rocha Gomes Torres}

To cite this article: Graziela Ribeiro Batista, Daphne Câmara Barcellos \& Carlos Rocha Gomes Torres (2016) Effect of adhesive type and composite viscosity on the dentin bond strength, Journal of Adhesion Science and Technology, 30:8, 842-850, DOI: 10.1080/01694243.2015.1125722

To link to this article: https://doi.org/10.1080/01694243.2015.1125722

\section{曲 Published online: 23 Dec 2015.}

\section{Submit your article to this journal $\widetilde{ }$}

Llll Article views: 66

View Crossmark data ¿

Citing articles: 2 View citing articles 5 


\title{
Effect of adhesive type and composite viscosity on the dentin bond strength
}

\author{
Graziela Ribeiro Batista, Daphne Câmara Barcellos and Carlos Rocha Gomes Torres \\ Department of Restorative Dentistry, Institute of Science and Technology, Univ. Estadual Paulista - UNESP, São \\ José dos Campos, Brazil
}

\begin{abstract}
Objectives: Evaluate the influence of composite resins viscosity and type of cure of the adhesive systems on the bond strength of composite resins submitted to artificial aging.

Methods: Dentin specimens $(n=240)$ were divided into 2 groups: Group GC: GrandioSO, and Group GF: GrandioSO Heavy Flow. These groups were subdivided into 6: FM: Futurabond M - light cured, FDCC: Futurabond Dual Cure - chemical cured, FDCL: Futurabond Dual Cure - light cured, CS3: Clearfil S3 - light cured, CDCC: Clearfil Dual Cure - chemical cured, and CDCL: Clearfil Dual Cure - light cured. Resin blocks were build up on the dentin surface. Half of samples on each group were cut to obtain resin/dentin sticks $(1 \times 1 \mathrm{~mm})$. The other half was first submitted to thermomechanical aging. The dentin/ resin sticks were submitted to microtensile bond strength test and the results were analyzed using three-way ANOVA and Tukey's test $(\alpha=5 \%)$.

Results: ANOVA showed significant influence for adhesive $(p=0.0000)$ and aging $(p=0.0001)$. No significant influence of the composite viscosity on bond strength was observed (ANOVA: $p=0.0861$ ). For adhesive, the results of Tukey's test (MPa) were CDCC: 13.44 ( \pm 5.13$)$ a; FM: 14,01 ( \pm 2.71$)$ a; CDCL: 14.51 ( \pm 4.98$)$ a; FDCC: $18.66( \pm 7.13)$ b; CS3: 18.80 ( \pm 6.50$)$ b; FDCL: 19.18 ( \pm 7.39$)$ b. For aging: AGED: 14.99 ( \pm 6.32$)$ a; NOT AGED: $17.87( \pm 5.97) b$.

Conclusion: Composite resin viscosities did not influence on the bond strength. Type of cure of the adhesives had influence on the bond strength. Thermomechanical aging decreased the bond strength.
\end{abstract}

\section{ARTICLE HISTORY}

Received 12 October 2015

Revised 21 November 2015

Accepted 24 November 2015

\section{KEYWORDS}

Composite resin; viscosity; self-etching adhesives; bond strength; microtensile bond strength

\section{Introduction}

The growing interest about esthetic dentistry caused large investments in research and development of restorative materials. Composite resins for direct restorations are one of them and have been widely employed. They offer good esthetic results, have satisfactory physical properties, are less clinical time consuming, and less expensive alternative comparing to the indirect restorations. 
The composite resins are composed of organic matrix and inorganic fillers, and these inorganic fillers are the responsible for the characteristics as physical resistance, improvement of hardness, reduction of polymerization stress, decrease in wear, and modification of viscosity.[1] In order to improve the physical properties and reduce the stress caused by the polymerization shrinkage, the addition of high quantities of inorganic fillers was considered an alternative. However, it affects directly the viscosity of the material, making it less flowable and more difficult to adapt into the cavities.[1,2] Flowable composites have a better ability to adapt to the cavities and because of their low elastic modulus they are supposed to be less affected by the polymerization shrinkage stress, reducing the risk of microleakge.[3-6] The problem of the conventional flowable composites is the lower filler content, that make worsens their mechanical properties. [7]

With the development of nanotechnology, smaller particles in a size range from 1 to $100 \mathrm{~nm}$ could be an alternative to include more filler content to composite resins. The advantage of the nanofillers is that they can behave as liquids in a certain degree. While a composite with $40 \%$ of microfillers content has a high viscosity, the viscosity of composite may be lower with the same concentration of nanofillers allowing addition of more fillers to the composite.[8] Meanwhile, the smaller is the particle, the bigger is the surface to volume, and these particles would attract to each other because of their surface energy. It would produce agglomerates and the mentioned advantages of nanofillers would be lost. To avoid this problem, each particle must receive a surface treatment, as a coating, with an organic-inorganic hybrid compound that is capable of creating a strong chemical connection between filler particles and resin matrix.[8] Using this technology, it is possible to include more filler content to composites with low viscosity, around $80 \%$ weight and $70 \%$ volume, while the conventional composite resins have around $60 \%$ weight and $45 \%$ volume.[9] It is supposed that flowable composite resins with high filler content can be used in areas of high occlusal impact because their mechanical properties are probably as good as the conventional composites. Besides that, their fluidity make them more user friendly, once they can be easily applied and could be better adapted to the cavities minimizing the risks of failure areas.

The self-etch adhesive systems (SEAs) are also considered as contributing to simplify the restorative technique. This system eliminates the previous use of phosphoric acid, decreasing the risks of over etching, which could let a non-impregnated area of exposed collagen fibrils under the hybrid layer that could be responsible for the adhesive fails.[10-14] It is believed that use of SEAs results in more homogeneous hybrid layer and consequently the restorations would be longer lasting. $[10,13,14]$ The SEAs are available in different forms of application, displayed in one bottle or two, and can also diversify regarding the type of cure, which can be physical, for the light cure systems, or can be also chemical for the dual cure system, that can polymerize without light activation. It is speculated that these differences can affect the bond strength, because different systems of application acting over dental tissues in different ways and then it could influence the characteristics of hybrid layers, as its thickness, continuity, and homogeneity.[14-16]

The adequate polymerization of adhesive layer is directly related to the success of the restorative procedure. If the polymerization stresses of composite resin occur over a not totally cured hybrid layer, it will result in consequently adhesive fails. [9] When light cure systems are used, light must reach the total extension of surface impregnated by SEA, otherwise non-cured areas can promote the fail of the adhesion. To avoid this problem, it is 
suggested to use the dual cure systems, where chemical cure occurs independently of the light.[17] Based on that, we can consider that different methods of cure could interfere on bond strength.

It is also important to consider that composite resins and SEAs will be submitted to oral conditions as temperature changes and masticatory stresses, and these factors can influence negatively the success of the restorative treatment.[18] Thus, these materials must be tested under these simulated conditions in vitro, in order to provide realistic results, and evaluate if different physical characteristics of different materials can really interfere on its behavior when submitted to thermal and mechanical stimulus.

Based on the exposed statements, the null hypotheses of this study were that (i) composite resin viscosity do not influence the bond strength; (ii) cure method of SEAs do not influence the bond strength; and (iii) artificial aging do not influence the bond strength.

\section{Material and methods}

Two hundred and forty freshly extracted bovine incisors were used. They were cleaned and stored in deionized water under refrigeration $\left(10^{\circ} \mathrm{C}\right)$ until the moment of use. They were evaluated using a stereomicroscope (Stemi 2000 C, Carl Zeiss; Jena, Germany) at 50X magnification to certify the absence of surface damage on the crowns. Their roots were sectioned at cement-enamel junction and removed. The buccal surfaces were ground using silicon carbide abrasive paper (FEPA-P400, Panambra, São Paulo, SP, Brazil), until a flat surface in dentin $(6 \times 6 \mathrm{~mm})$ was obtained. After that, openings were made in the lingual surface using a spherical diamond bur to allow the use of a caliper to measure the dentin thickness, which should have a minimum of $2 \mathrm{~mm}$. The teeth were embedded in acrylic resin using a silicone mold. The smear layer of the specimens were standardized using silicon carbide abrasive paper with a grit size of P600 (FEPA) for $30 \mathrm{~s}$ under tap water, in accordance with ISO/TS 11,405.

Experimental groups were divided according to the viscosity of the composite used: C - Conventional viscosity GrandioSO (Voco, Cuxhaven, Germany) and F - Flowable viscosity GrandioSO Heavy Flow (Voco, Cuxhaven, Germany). Each group was subdivided according to the adhesive system used and the type of cure adopted for them: FM - Futurabond M (Voco, Cuxhaven, Germany), light cured; FDCC - Futurabond Dual Cure (Voco, Cuxhaven, Germany), chemical cured; FDCL - Futurabond Dual Cure, light cured; CS3 - Clearfil S3 Bond (Kuraray, Tokyo, Japan), light cured; CDCC Clearfil Dual Cure (Kuraray, Tokyo, Japan), chemical cured; and CDCL - Clearfil Dual Cure, light cured. The adhesive systems were applied according manufacturer's instructions. Dentin was dried using absorbent paper; the adhesives were applied with disposable applicator under agitation for $20 \mathrm{~s}$, gently air dried for $5 \mathrm{~s}$. The distance of the syringe was standardized $10 \mathrm{~cm}$ from the dentin surface. Light cured groups were cured (1000 mW/ $\mathrm{cm}^{2}$, Schuster LED, Santa Maria, RS, Brazil) for $10 \mathrm{~s}$. Groups submitted to chemical cure were kept protected from light for $3 \mathrm{~min}$.

After the application of adhesive systems, composite resin blocks $(5 \times 5 \times 2 \mathrm{~mm})$ were build up using silicon molds. The composite resin was inserted in one increment, and light cured for $20 \mathrm{~s}$ (Schuster LED, Santa Maria, RS, Brazil). After that, each side of the block received additional light curing for $20 \mathrm{~s}$ each. The specimens were stored in deionized water at $37^{\circ} \mathrm{C}$ for $24 \mathrm{~h}$. After that, half of the specimens of each group were submitted to 
Table 1. Materials used, manufacturers, composition, and batch number.

\begin{tabular}{|c|c|c|c|}
\hline Material & Manufacturer & Composition & Batch Numbero \\
\hline GrandioSO & $\begin{array}{l}\text { Voco, Cuxhaven, } \\
\text { Alemanha }\end{array}$ & $\begin{array}{l}\text { Resin matrix: } \\
\text { Bis-GMA, BisEMA, TEGDMA, CQ, Amine, BHT. } \\
\text { Inorganic content: } \\
\text { Nanoparticles of } \mathrm{SiO}_{2}: 20-40 \mathrm{~nm} \text {; glass ceramic: } \\
\quad 1 \mu \mathrm{m} \text {. } \\
\text { Filler Content: } \\
89 \% \text { weight and } 73 \% \text { volum. }\end{array}$ & 1.029 .391 \\
\hline $\begin{array}{l}\text { Grandioso heavy } \\
\text { flow }\end{array}$ & $\begin{array}{l}\text { Voco, Cuxhaven, } \\
\text { Alemanha }\end{array}$ & $\begin{array}{l}\text { Resin matrix: } \\
\text { Bis-GMA, BisEMA, TEGDMA, CQ, Amine, BHT. } \\
\text { Inorganic content: } \\
\text { Nanoparticles of } \mathrm{SiO}_{2}: 20-40 \mathrm{~nm} \text {; glass ceramic: } \\
\quad 1 \mu \mathrm{m} \text {. } \\
\text { Filler Content: } \\
83 \% \text { weight and } 68 \% \text { volum. }\end{array}$ & 1.123 .233 \\
\hline Futurabond $\mathrm{M}$ & $\begin{array}{l}\text { Voco, Cuxhaven, } \\
\text { Alemanha }\end{array}$ & $\begin{array}{l}\text { UDMA, HEMA, methacroyl phosporic acid ester, } \\
\text { camphorquinone, BHT and ethanol. }\end{array}$ & 1.025 .303 \\
\hline Futurabond DC & $\begin{array}{l}\text { Voco, Cuxhaven, } \\
\text { Alemanha }\end{array}$ & $\begin{array}{l}\text { Bis-GMA, HEMA, TMPTMA, methacroyl phosporic } \\
\text { acid ester, camphorquinone, BHT and ethanol. }\end{array}$ & 1.030 .392 \\
\hline Clearfil $S^{3}$ bond & $\begin{array}{l}\text { Kuraray } \\
\text { Tóquio, Japan }\end{array}$ & $\begin{array}{l}\text { Bis-GMA, HEMA, camphorquinone, MDP, hydro- } \\
\text { fobic dimethacrylate, ethyl alcohol, water and } \\
\text { colloidal silica. }\end{array}$ & 000.210 \\
\hline Clearfil DC & $\begin{array}{l}\text { Kuraray } \\
\text { Tóquio, Japan }\end{array}$ & $\begin{array}{l}\text { Bis-GMA, HEMA, camphorquinone, MDP, benzoyl } \\
\text { peroxide, ethanol, water and colloidal silica. }\end{array}$ & $\begin{array}{l}\text { Liquid A: } 00.025 \\
\text { Liquid B: } 00.018\end{array}$ \\
\hline
\end{tabular}

thermomechanical aging (ER 3700, Erios, São Paulo, SP, Brazil) for 300.000 mechanical cycles $(88,4 \mathrm{~N})$ and 1000 thermal cycles, where the temperatures were changing from low to high levels $\left(5 \pm 2{ }^{\circ} \mathrm{C}, 37 \pm 2{ }^{\circ} \mathrm{C}\right.$ e $\left.55 \pm 2{ }^{\circ} \mathrm{C}\right)$. The materials, their composition, batch number, and manufacturers are listed in Table 1 and the physical properties of composites are listed in Table 2.

The aged and not aged specimens were longitudinally sectioned in both directions across the bonded interface, using a diamond saw in a cut machine (Labcut Extec; Enfield, CT, USA) at $300 \mathrm{rpm}$ under water cooling, to obtain bonded sticks with a cross-sectional area of approximately $1 \mathrm{~mm}^{2}$. Each specimen provided about nine sticks. The cross-sectional area of each stick was measured with the digital caliper (Absolute Digimatic, Mitutoyo; Tokyo, Japan). The values (around $1 \mathrm{~mm}^{2}$ ) were recorded for subsequent calculation of the microtensile bond strength. Each bonded stick was submitted to the microtensile bond strength test using the L2500 specimen holder (Erios; Sao Paulo, SP, Brazil). The analyses were performed using a universal testing machine (DL200MF, Emic; Sao José dos Pinhais, $\mathrm{SC}$, Brazil) at a speed of $1 \mathrm{~mm} / \mathrm{min}$. The obtained data (MPa) were submitted to Kolmogorov

Table 2. Values for physical properties of the composite resins ${ }^{[9]}$.

\begin{tabular}{lcc}
\hline Properties & Conventional & Flow \\
\hline Elastic modulus (GPa) & 21.62 & 12.85 \\
Microhardness (KHN) & 93.19 & 40.27 \\
Polymerization shrinkage (\%) & 2.56 & 3.66 \\
Polymerization tension (N) & 3.51 & 6.22 \\
\hline
\end{tabular}


Table 3. Results of three-way ANOVA statistical analysis.

\begin{tabular}{lcccc}
\hline Factors & df & MS & $F$ & $p^{*}$ \\
\hline Composite resin & 1 & 87.83 & 2.972 & 0.0861 \\
Adhesive system & 5 & 292.88 & 9.911 & $0.0000^{*}$ \\
Aging & 1 & 496.89 & 16.816 & $0.0001^{*}$ \\
Composite resin $\times$ Adhesive system & 5 & 50.91 & 1.723 & 0.1305 \\
Composite resin $\times$ aging & 1 & 33.37 & 1.129 & 0.2891 \\
Adhesive system $\times$ aging & 5 & 98.90 & 3.347 & $0.0062^{*}$ \\
Composite resin $\times$ Adhesive system $\times$ aging & 5 & 57.93 & 1.961 & 0.0857 \\
\hline
\end{tabular}

*Significant statistical differences.

Table 4. Results of Tukey's test to the factor adhesive system (MPa).

\begin{tabular}{|c|c|c|}
\hline Adhesive system & Mean $( \pm S D)$ & Homogeneous groups* \\
\hline $\mathrm{CDCC}$ & $13.44( \pm 5.13)$ & A \\
\hline FM & $14.01( \pm 2.71)$ & $A$ \\
\hline$C D C L$ & $14.51( \pm 4.98)$ & $A$ \\
\hline FDC C & $18.66( \pm 7.13)$ & B \\
\hline $\mathrm{CS}^{3}$ & $18.80( \pm 6.50)$ & B \\
\hline $\mathrm{FDCL}$ & $19.18( \pm 7.39)$ & $\mathrm{B}$ \\
\hline
\end{tabular}

*Groups followed by same letters show not significant statistical differences.

Table 5. Results of Tukey's test to the factor aging (MPa).

\begin{tabular}{|c|c|c|}
\hline Aging & Mean $( \pm S D)$ & Homogeneous sets* \\
\hline With & $14.99( \pm 6.32)$ & A \\
\hline Without & $17.87( \pm 5.97)$ & B \\
\hline
\end{tabular}

*Groups followed by same letters show not significant statistical differences.

Smirnov's normality test and then to statistical analysis using three-way ANOVA and Tukey's test $(\alpha=5 \%)$.

\section{Results}

The Table 3 shows the results of three-way ANOVA for the factors: composite resin, adhesive system, and aging, and for interaction among them.

According the results presented in Table 3, only the factors adhesive system and aging showed significant differences and also the interaction between these factors. Table 4 shows the results of Tukey's test to the factor adhesive system.

In Table 4, it is possible to observe that regarding one-step adhesive systems with two components, light or chemical cured, Clearfil DC showed lower values of bond strength than Futurabond DC. Regarding one-step adhesive systems with one component, Clearfil $S^{3}$ shows better results than Futurabond $\mathrm{M}$.

Evaluating the type of cure for the same adhesive systems, light or chemical cured did not influenced the results significantly, although the mean values for the light cured being higher than chemical cured. As shown in Table 5, samples submitted to thermomechanical aging showed lower values of bond strength.

Figure 1 shows the mean values of bond strength for different types of composite resin and adhesive systems, with or without thermo-mechanical aging. 


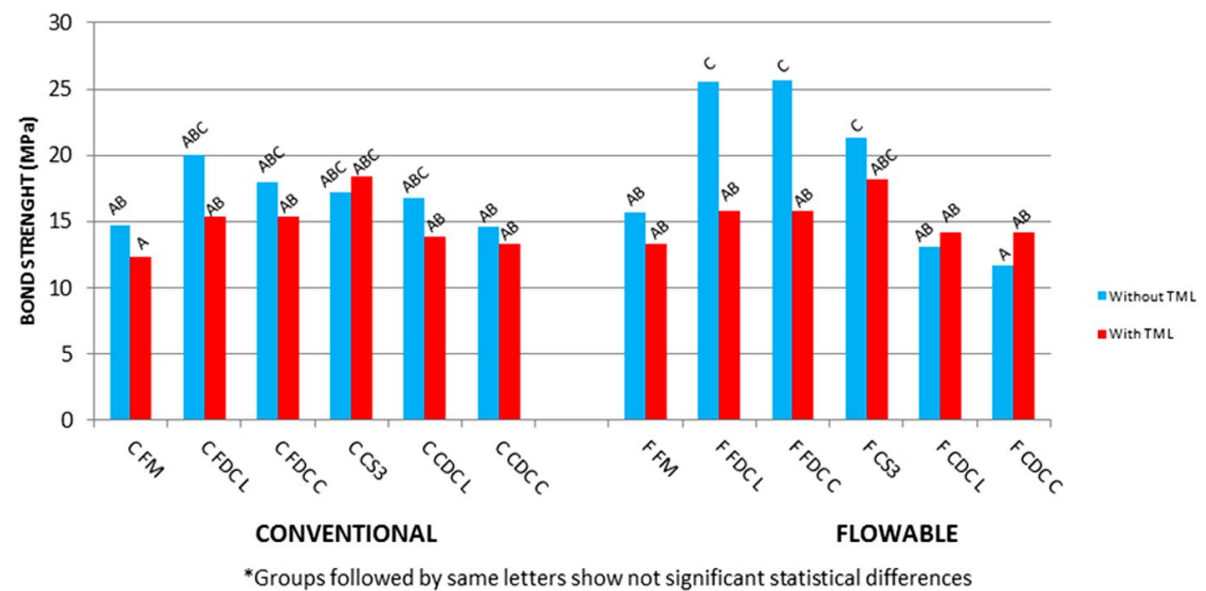

Figure 1. Mean values of bond strength for different experimental groups.

\section{Discussion}

Flowable composite resins are easier to apply than conventional viscous composites. This characteristic of the material decreases the risk of failure areas inside the restoration, because as the material is more fluid it has a better capacity of adapting to the cavity walls. Previous study [19] suggested that wettability of flowable materials reduces the contact angle between bonding substrates. Interaction between materials and resin surface energy could strongly affect bond strength.[20] Low elastic modulus is another advantage of these materials, these materials are more flexible which promotes shrinkage polymerization stresses, but make them less susceptible to masticatory stresses.[21] The addition of high filler content to flowable composites would make them available for use in areas of masticatory stress. According to the results obtained in this study, the first null hypothesis was accepted since the different composites viscosities had no significant influence on bond strength. These data correlate to a clinical study [22] performed with the same composites, after 24 months GrandioSO and GrandioSO Heavy Flow did not show statistical difference for evaluated parameters. Similar composition of the composites as well same type and size of filler are supposed the reason to similar behavior of the materials.

The second null hypothesis therefore has to be rejected because the results showed significant differences among the tested adhesive systems. When analyzing different curing methods, no significant statistical difference exists between the light cured or chemical cured groups for the same adhesive system; however, the difference was significant comparing evaluated systems. Futurabond DC had a better performance than Clearfil DC for both curing methods. Considering the acidity of the materials, Futurabond DC is classified as strong $(\mathrm{pH}=1.4)$, while Clearfil $\mathrm{DC}$ is classified as mild $(\mathrm{pH}=2.7)$. As lower the $\mathrm{pH}$ of the material, higher its ability to remove smear layer $[23,24]$ creating thicker hybrid layers.[13,25] Thickness of smear layer could improve bond strength due to deeper dentin infiltration that creates longer adhesive tags and promote better micromechanical retention. Previous study [26] showed Futurabond DC could penetrate dentin in a depth around 10-30 $\mu \mathrm{m}$, similar to the values reached with etch and rinse systems. Although some studies do not relate stronger acidity to better bond strength results, $[13,25,26]$ it is speculated that in this study it could have some influence. 
Chemical composition of the materials is also an important factor to be considered. Manufacturer's description sheet of Futurabond DC describes there is TMPTMA in its composition. This component is a low viscosity water-insoluble trifunctional methacrylate monomer,[27] which is speculated could make adhesive layer more resistant to hydrolitic degradation.

In the other hand, for adhesive systems exclusively light cured, Clearfil $S^{3}$ Bond had better performance than Futurabond M. Regarding $\mathrm{pH}$ values, both are considered mild, Clearfil $\mathrm{S}^{3}$ Bond has a $\mathrm{pH} 2.3$ and Futurabond $\mathrm{M}$ has a $\mathrm{pH}$ 2. The significant difference on results can be again explained by the chemical composition of the materials. Functional monomer of Clearfil $S^{3}$ Bond is MDP, which is able to chemically connect to hydroxyapatite from dental tissues and besides that is more resistant to hydrolytic degradation because it is self-assembled in nanolayers strongly hydrophobic, protecting the hybrid layer.[28] Clearfil DC also has MDP in its composition, but we suppose that some chemical interaction occurs between Futurabond DC and composites used to explain the better results obtained in those groups. However, further studies are necessary to prove this affirmative. Even though this study did not test degree of conversion of adhesive systems, MDP and Bis-GMA, both present in Clearfil S ${ }^{3}$ Bond were described before [29] as components that promote high degrees of conversion of the adhesive systems and it could affect the quality of hybrid layer and consequently the bond strength. Differently, functional monomer of Futurabond M is UDMA, considered medium viscosity monomer, previously reported [30] as prone to high levels of shrinkage stress in short time periods, leading to the supposition that it could jeopardize bond strength.

Thermomechanical aging had a significant influence on bond strength; thus third null hypothesis was also rejected. Although the values in Table 5 show that there is a significant statistical difference between the groups with and without thermomechanical aging, the standard deviation would suggest that could occur an overlap of the bond strength values, which could be an indication that thermomechanical aging may not have such a big influence on bond strength. Results on Figure 1 show that statistical difference before and after aging were significant only for Futurabond DC associated to flowable composite. The stronger acidity of this material was supposed to influence on it. Strong acidity materials can retain acidic monomers and remain etching as consequence of incomplete polymerization. $[25,31]$ It could contribute for decrease in bond strength values. Besides that, it is important to highlight that artificial aging has a deleterious effect on adhesive interface because it can accelerate chemical degradation [32] and also due to different coefficient of thermoexpansion of dental tissues and restorative materials.[33] As they suffer contraction/expansion in different levels, adhesive layer is under stress and susceptible to failures. Artificial aging negative effect is not only on adhesive interface but also on restorative materials because they can have small defects that under mechanical stress concentrate more tension leading to dissemination of defects that can even result in rupture of adhesion. [34]

Although the results of the current study have shown good results for flowable composites and dual cured adhesive systems using only chemical cure method, further evaluations, especially regarding chemical interactions of the materials, are necessary to assure the reliability of the materials under diverse clinical situations. 


\section{Conclusion}

Within the limitations of this in vitro study, we conclude that neither different viscosities of composite resins nor chemical cure method for dual cure adhesive systems had significant influence on the bond strength to dentin. Thermomechanical aging decreases bond strength but it was significant only for Futurabond DC associated to flowable composite.

\section{Clinical relevance}

New materials with high filler content are described as adequate for use in posterior teeth. Besides that, different cure of self-etch adhesive systems can be combined to the composites and it could also have some influence on bond strength to dentin.

\section{Disclosure statement}

No potential conflict of interest was reported by the authors.

\section{References}

[1] Rawls H, Esquivel-Upshaw J. Resinas restauradoras. In: Anusavice KJ, editor. Phillips materiais dentários. 11 aed ed. Rio de Janeiro: Elsevier; 2005. p. 375-417.

[2] Weinmann W, Thalacker C, Guggenberger R. Siloranes in dental composites. Dent. Mater. 2005;21:68-74. Epub 2005/02/01.

[3] Labella R, Lambrechts P, Van Meerbeek B, et al. Polymerization shrinkage and elasticity of flowable composites and filled adhesives. Dent. Mater. 1999;15:128-137. Epub 1999 Nov 07.

[4] Kubo S, Yokota H, Hayashi Y. Effect of low-viscosity resin-based composite on the microleakage of cervical restorations. Am. J. Dent. 2003;16:244-248. Epub 2003 Oct 29.

[5] Kubo S, Yokota H, Hayashi Y. Microleakage of cervical cavities restored with flowable composites. Am. J. Dent. 2004;17:33-37. Epub 2004 Jul 10.

[6] Unterbrink GL, Liebenberg WH. Flowable resin composites as "filled adhesives": literature review and clinical recommendations. Quintessence Int. 1999;30:249-257. Epub 2000 Jan 15.

[7] Bayne SC, Thompson JY, Swift EJ, et al. A characterization of first-generation flowable composites. J. Am. Dent. Assoc. 1998;129:567-577. Epub 1998 May 28.

[8] VOCO. Grandio SO scientific product information cuxhaven: VOCO GmbH; 2012 [cited 2012 Aug 09]. Available from: http://www.voco.com/en/products/_products/GrandioSO/ VC_84_002610_1110_GB_V.pdf

[9] Gutierrez NC, Batista GR, Borges AB, Pucci CR, Torres CRG. Influence of Composite Viscosity and Adhesives Systems on Microleakage/Gap. In: 89th General Session \& Exhibition of the IADR, 2011, San Diego. 89th General Session \& Exhibition proceedings, 2011.

[10] Cardoso MV, Coutinho E, Ermis RB, et al. Influence of dentin cavity surface finishing on micro-tensile bond strength of adhesives. Dent. Mater. 2008;24:492-501Epub 2007 Aug 07.

[11] Dias WR, Pereira PN, Swift EJ. Effect of bur type on microtensile bond strengths of self-etching systems to human dentin. J. Adhes. Dent. 2004;6:195-203. Epub 2004 Nov 13.

[12] Oliveira SS, Pugach MK, Hilton JF, et al. The influence of the dentin smear layer on adhesion: a self-etching primer vs. a total-etch system. Dent. Mater. 2003;19:758-767. Epub 2003 Sep 27.

[13] Kenshima S, Reis A, Uceda-Gomez N, et al. Effect of smear layer thickness and pH of selfetching adhesive systems on the bond strength and gap formation to dentin. J. Adhes. Dent. 2005;7:117-126. Epub 2005 Aug 2.

[14] Reis A, Grandi V, Carlotto L, et al. Effect of smear layer thickness and acidity of self-etching solutions on early and long-term bond strength to dentin. J. Dent. 2005;33:549-559. Epub 2005 Jul 12. 
[15] Sattabanasuk V, Vachiramon V, Qian F, et al. Resin-dentin bond strength as related to different surface preparation methods. J. Dent. 2007;35:467-475. Epub 2007 Mar 03.

[16] Reis A, Carrilho M, Loguercio A, et al. Current adhesive systems. Jornal Brasileiro de Clinica Odontologica Integrada. 2001;5:457-465.

[17] de Menezes MJ, Arrais CA, Giannini M. Influence of light-activated and auto- and dualpolymerizing adhesive systems on bond strength of indirect composite resin to dentin. J. Prosthetic Dent. 2006;96:115-121. Epub 2006 Aug 17.

[18] Trowbridge HO. Model systems for determining biologic effects of microleakage. Operative Dent. 1987;12:164-172. Epub 1987 Jan 01.

[19] de Souza G, Hennig D, Aggarwal A, et al. The use of MDP-based materials for bonding to zirconia. J. Prosthet. Dent. 2014;12:895-902. Epub 2014 Apr 29.

[20] Kim MJ, Kim YK, Kim KH, et al. Shear bond strengths of various luting cements to zirconia ceramic: surface chemical aspects. J. Dent. 2011;39:795-803. Epub 2011 Sep 13.

[21] Reis AF, Bedran-Russo AK, Giannini M, et al. Interfacial ultramorphology of single-step adhesives: nanoleakage as a function of time. J. Oral Rehabil. 2007;34:213-221Epub 2007 Feb 17.

[22] Torres CRG, Rêgo HM, Perote LC, et al. A split-mouth randomized clinical trial of conventional and heavy flowable composites in class II restorations. J. Dent. 2014;42:793-799. Epub 2014 Apr 29.

[23] Tay FR, Pashley DH. Aggressiveness of contemporary self-etching systems. Dent. Mater. 2001;17:296-308. Epub 2001 May 18.

[24] Kenshima S, Francci C, Reis A, et al. Conditioning effect on dentin, resin tags and hybrid layer of different acidity self-etch adhesives applied to thick and thin smear layer. J. Dent. 2006;34:775-783. Epub 2006 Apr 20.

[25] De Munck J, Vargas M, Iracki J, et al. One-day bonding effectiveness of new self-etch adhesives to bur-cut enamel and dentin. Operative Dent. 2005;30:39-49. Epub 2005 Mar 16.

[26] Wagner A, Wendler M, Petschelt A, et al. Bonding performance of universal adhesives in different etching modes. J. Dent. 2014;42:800-807. Epub 2014 May 13.

[27] BASF. Trimethylolpropane trimethacrylate (TMPTMA): BASF group. 2011. Available from: www.specialty-monomers.basf.com

[28] Yoshida Y, Yoshihara K, Nagaoka N, et al. Self-assembled nano-layering at the adhesive interface. J. Dent. Res. 2012;91:376-381. Epub 2012 Feb 04.

[29] Hass V, Luque-Martinez I, Sabino NB, et al. Prolonged exposure times of one-step self-etch adhesives on adhesive properties and durability of dentine bonds. J. Dent. 2012;40:1090-1102. Epub 2012 Sep 29.

[30] Atai M, Watts DC, Atai Z. Shrinkage strain-rates of dental resin-monomer and composite systems. Biomater. 2005;26:5015-5020. Epub 2005 Mar 17.

[31] Wang Y, Spencer P. Continuing etching of an all-in-one adhesive in wet dentin tubules. J. Dent. Res. 2005;84:350-354. Epub 2005 Mar 26.

[32] Gale MS, Darvell BW. Thermal cycling procedures for laboratory testing of dental restorations. J. Dent. 1999;27:89-99. Epub 1999 Mar 11.

[33] De Munck J, Van Landuyt K, Peumans M, et al. A critical review of the durability of adhesion to tooth tissue: methods and results. J. Dent. Res. 2005;84:118-132. Epub 2005 Jan 26.

[34] Griffith AA. The phenomena of rupture and flow in solids. Philos. Trans. R. Soc. London, Ser. A: Math., Phys. Eng. Sci. 1921;221:163-198. 